\title{
DEVELOPMENT OF THE POLLEN IN THE ANTARCTIC FLOWERING PLANT COLOBANTHUS QUITENSIS (KUNTH) BARTL.
}

\author{
Irena Gielwanowska ${ }^{1,2}$, Anna Bochenek ${ }^{1}$, Ewa Szczuka ${ }^{3}$ \\ ${ }^{1}$ Department of Plant Physiology and Biotechnology, University of Warmia and Mazury, Oczapowskiego 1A, 10-719 Olsztyn, Poland \\ e-mail:i.gielwanowska@uwm.edu.pl \\ ${ }^{2}$ Department of Antarctic Biology, Polish Academy of Sciences, Ustrzycka 10/12, 02-141 Warsaw, Poland \\ ${ }^{3}$ Department of Plant Anatomy and Cytology, UMCS University, Akademicka 19, 20-033 Lublin, Poland
}

Received: 20.10.2007

\section{S u m m a r y}

Colobanthus quitensis (Kunth) Bartl. produced two types very small bisexual flowers. In the Antarctic natural conditions chasmogamic and cleistogamic flowers most often form five stamina with short filaments. Two microsporangia with a three-layer wall form in the anther. Microspore mother cells, which develop into microspores after meiosis, form inside the microsporangium. Microsporocytes of Colobanthus quitensis are surrounded with a thick callose layer, the special wall. After meiosis, the callose wall is dissolved and microspores are released from the tetrad. The production of proorbicules, orbicules and peritapetal membrane, and the construction of a complex sporoderm with numerous apertural sites were observed. When microspore and pollen protoplasts underwent necrosis, probably as a result of temperature and osmotic stress, sporoderm layers formed around microspores, and the cell tapetum did not disintegrate. However, woody wall layers did not accumulate in endothecium cells.

Key words: Colobanthus quitensis, microsporangia, microsporogenesis, male gametophytes, tapetal cells

\section{INTRODUCTION}

Colobanthus quitensis (Kunth) Bartl. is the only flowering dicot of the Antarctica. It has grown together with Deschampsia antarctica Desv. (Poaceae) for a few thousand years. It effectively colonises surfaces of the Antarctic geobotanical zone uncovered by melting ice (Edwards, 1974; A lberdi et al. 2002). In the extremely hostile Antarctic conditions, Colobanthus quitensis (Caryophyllaceae) flowers profusely almost every year. After pollination and fertilization it produces seeds. Antarctic pearlwort seeds are often dead due to unfavourable microhabitat conditions and the short cold summer (Convey, 1996; G i e łw a now ska et al. 2006).
The summer season is considered to last for about 5 months, more or less from November to March, taking especially day and night length into account. Considering the length of the snow-cover period in the areas uncovered by ice, the growth season of seminiferous plants occurring here may be shortened by 1-2 months. Irrespective of other factors affecting the plants, this time is critical for the formation of generative cells and seeds (Edwards, 1974; Giełwanowska et al. 2006).

Macroscopic observations of flower and seed development in Antarctic pearlwort and Antarctic hair grass were conducted in various areas of the Maritime Antarctic and in different growth seasons. Greene and Holtom (1971) described the flower formation in $\mathrm{Co}$ lobanthus quitensis and Deschampsia antarctica on the South Orkney Islands. B r o w n (1912) and H o l d g a te (1964) observed specimens of Antarctic pearlwort and hair grass which flowered and dispersed seeds in the communities of South Georgia, while Holtom and Greene (1967) on some of the South Shetland Islands.

As only few descriptions of generative cell development in Antarctic flowering plants have been published (Giełwan ow ska, 2005; Gi ełwan o w ska et al. 2005; Giełwanowska et al. 2006), in this work we present some stages of microsporogenesis and pollen development in Colobanthus quitensis.

\section{MATERIALS AND METHODS}

The experimental materials were flower buds of Colobanthus quitensis in different development stages. The materials were collected during the $26^{\text {th }}$ expedition to the Antarctic, organized by the Department of Antarctic Biology, Polish Academy of Sciences in Warsaw. Flower buds of Colobanthus quitensis were collected 
during the Antarctic summer, from December 2001 to March 2002, in the vicinity of the Arctowski Polar Station $\left(62^{\circ} 09.8^{\prime} \mathrm{S}\right.$ and $\left.58^{\circ} 28.5^{\prime} \mathrm{W}\right)$.

\section{Light and electron microscopy}

The material for light and electron microscopy was prepared by a standard method, i.e. fixed in an osmic acid-glutaraldehyde solution. The material was dehydrated in an alcohol-acetone series, and embedded in Poly Bed 812 epoxy resin. Semi-thin and ultra-thin sections were prepared in a Leica (Ultracut R) ultramicrotome, using glass and diamond knives, stained with toluidine blue, and toluidine blue and azure B, following P e ar s e (1962), and then examined and photographed under a light microscope, models Olympus and Nikon Optiphot II. All preparations to be photographed under a light microscope were mounted in glycerin. Ultra-thin sections $(60-90 \mathrm{~nm})$ were placed onto a copper wire gauze (300 meshes) and contrasted with a saturated aqueous solution of uranyl acetate and lead citrate, following R e y n o ld s (1973). Observations and electronograms were made in a JEOL JEM 100S transmission electron microscope.

\section{RESULTS}

Colobanthus quitensis flowers usually produced 5 stamina with short filaments.

In the anther there were two microsporangia, which had a regular circular shape in cross section. Four cell layers were visible in the microsporangium wall. The most external layer was epidermis under which, almost on its entire length, there was a layer of starch-filled cells which transformed into endothecium. Only at some places there was a middle layer of parenchyma. A nutritive tissue, tapetum (Fig. 1), developed inside. The central part of the microsporangium was occupied by archesporial tissue from which, as a result of meiosis, microspores were formed. Before meiosis began, microspore mother cells constructed special callose walls. Callose surrounded microsporocytes until the tetrad stage. After meiosis, when callose disintegrated, microspores were released from the tetrads, and a complex cell wall, sporoderm, formed on the surface of their protoplasts.

The developing mother cells of the male gametophyte, from the premeiotic stage, through meiosis, to the stage of double-cell pollen grains (Fig. 2), were surrounded and nourished by the cell tapetum. Cells of the secretory tapetum contained one or two nuclei. They retained their individuality until the gametophyte stage. In the thick cytoplasm of tapetal cells, before microspores were released from the tetrads, osmophillic droplets appeared and moved inside the pollen sac (Fig. 3). Apart from small lipid droplets, vast areas containing such material visible within the cytoplasm and on the borderline with the pollen sac, could be observed in the tapetal cells. This material, in the form of proorbicules, moved from various areas of the tapetum towards pollen grains, and in the form of bigger structures, orbicules, joined the developing sporoderm (Fig. 5 ). A dozen or so of apertural sites devoid of electron-dense sporopollenin material (Fig. 5, ap) differentiated in the forming sporoderm. In the semi-thin sections, stained with toluidine blue, proorbicules and orbicules were visible in the form of blue-green drops (Fig. 5 and Fig. 6). Orbicules settled on the surface of pollen grains until the final stage of tapetal disintegration and atrophy. At the same time, endothecium with conspicuous ridge-like wall thickenings was already fully developed in the microsporangium wall (Fig. 5).

It is worth noting that, in the case of microspore or pollen protoplast necrosis, as a result of temperature or osmotic stress, tapetum did not disintegrate, and endothecium with woody ridges did not develop, although layers were almost normally deposited on the sporoderm (Fig. 3).

When pollen was mature and contained a bicellular and tricellular male gametophyte, Colobanthus quitensis microsporangia burst open at a specific site, stomium, on the inner (adaxial) side of the anther (Fig. 4 and Fig. 7). After anther dehiscence some pollen reached the surface of the receptive cells on the five-part feathery stigma, while some remained inside the microsporangium and germinated (Fig. 4).

\section{DISCUSSION}

A small number of microspore mother cells differentiated in each of the two microsporangia of the Colobanthus quitensis anther. However, already in the early first meiotic prophase these cells were surrounded with a thick callose wall and were isolated in this way until the tetrad stage. Callose began to hydrolise when the construction of sporoderm started, just as in other plants (Heslop-Harrison et al. 1986 ).

Microsporgenesis in Deschampsia antarctica was completely different. In the microsporocyte cell walls of the Antarctic hair grass, deposition of a thick callose layer was not observed. From the stage of sporogenic tissue cells, through all the meiotic stages, to tetrads, microsporocyte cell walls of the Antarctic hair grass remained thin. This feature distinguishes Deschampsia antarctica from other grasses, in which callose special walls of meiotic cells are common (McQuade and Young-Rottler, 1984; Rodkiewicz et al. 1996), as in other angiosperms (P a c in i et al. 1985).

In the microspore of Colobanthus quitensis, after the first mitosis, the formed generative nucleus does not break off the sporoderm, but remains firmly attached to the inner surface of the pollen wall. After mitosis, the generative cell stays close to the sporoderm, but it is separated from the vegetative cell by a very delicate wall with a little amount of fibrous material. The typical wall 

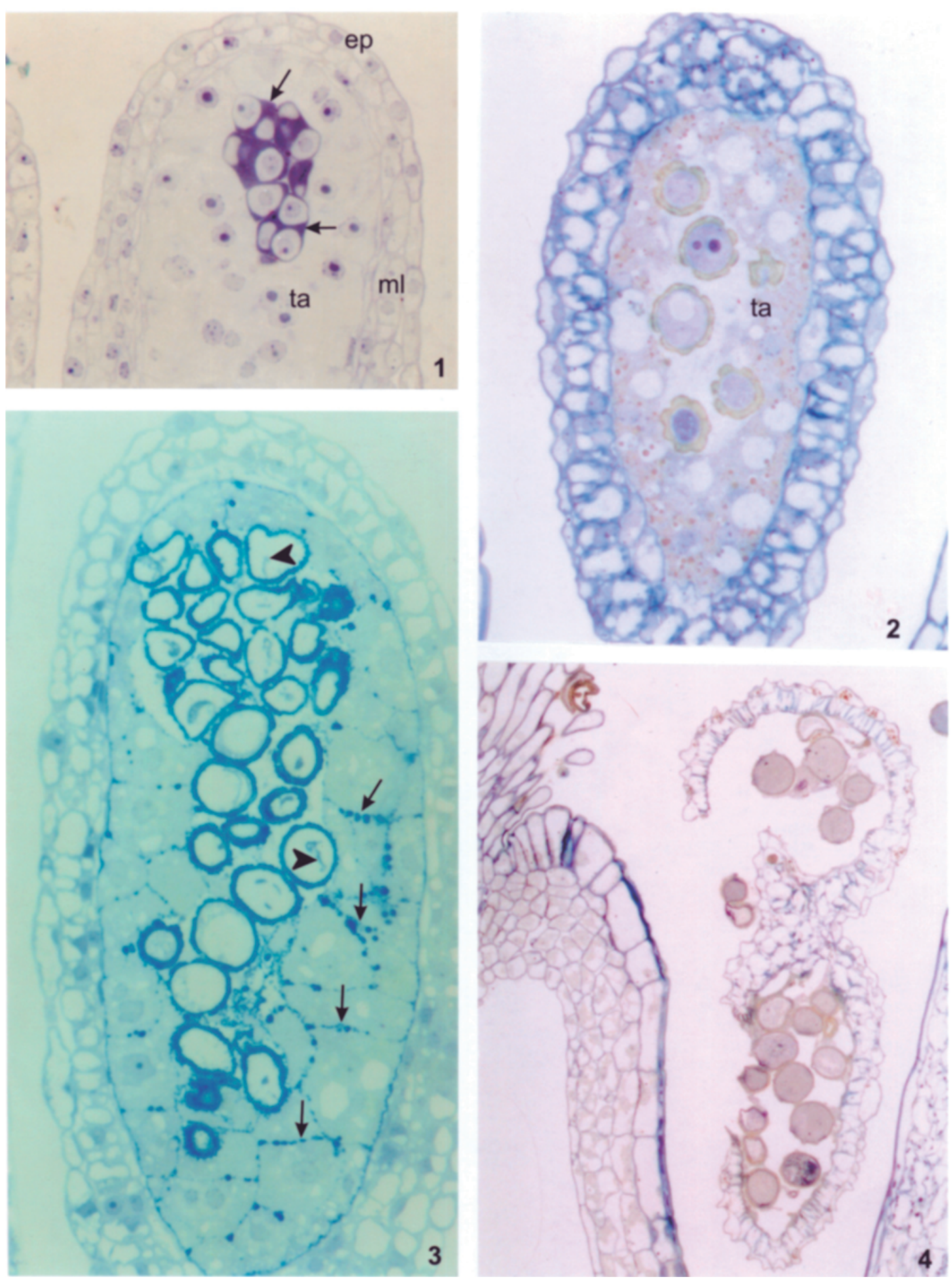

Fig. 1. Fragment of a microsporangium in Colobanthus quitensis. Layers of the wall; tapetum (ta), parenchymal middle layer (ml) and epidermis (ep). Very thick callose walls (arrows) of the microspore mother cells are visible. $1200 \mathrm{x}$.

Fig. 2. Binucleate pollen grains are visible in the microsporangium. Tapetum is disintegrated (ta). $2000 \mathrm{x}$.

Fig. 3. Microsporangium with disturbed pollen development. There is no developed endotecium in the microsporangium wall. Tapetum with dense, osmophilic drops (arrows) is visible. Pollen grains have well-developed sporoderm and degenerated contents (arrowheads). $2000 \mathrm{x}$.

Fig. 4. Longitudinal section of a closed flower bud with pollen grains in open microsporangia. Some of the pollen grains are germinating. $1200 \mathrm{x}$. 

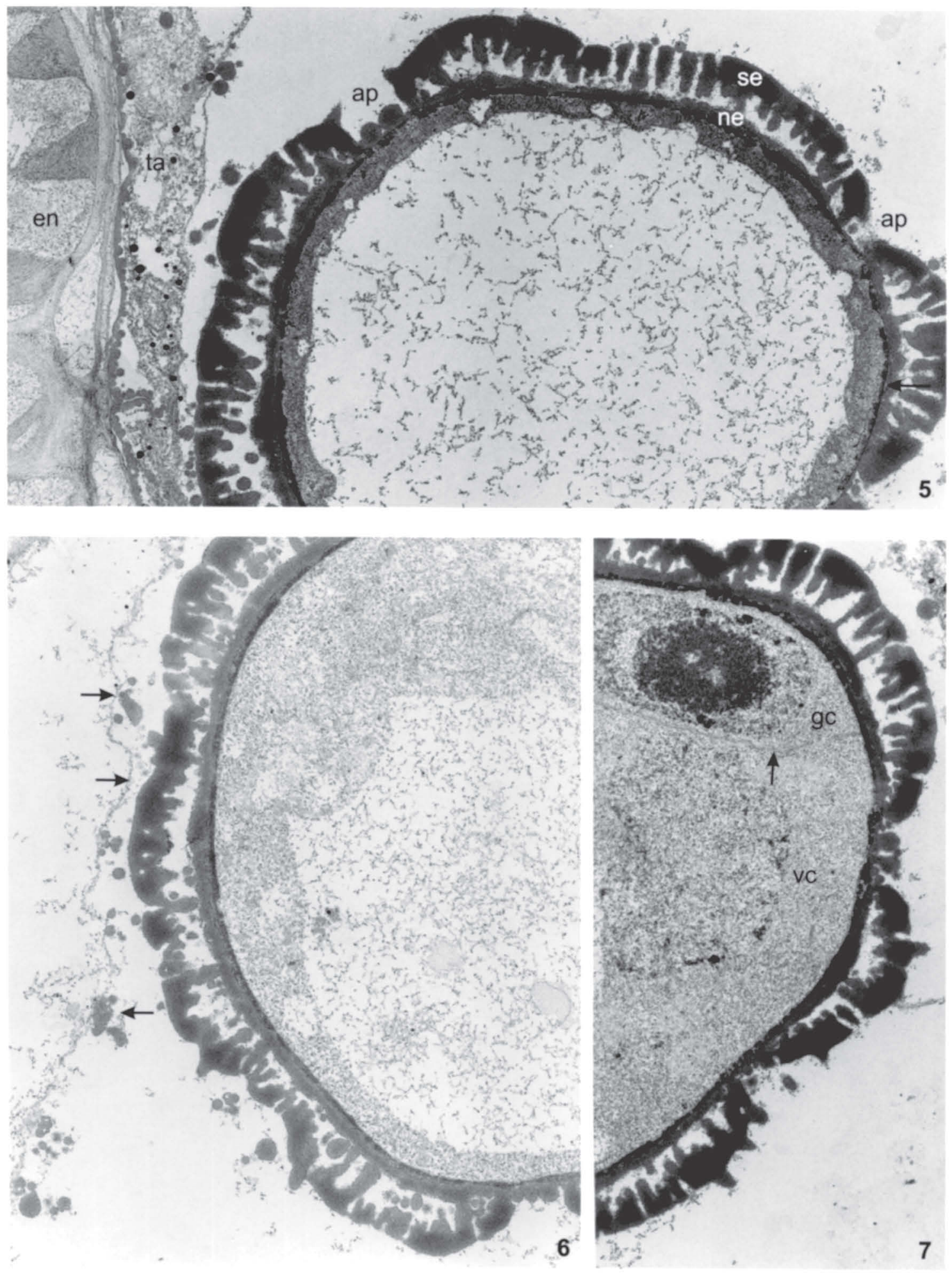

Fig. 5. Maturing pollen grain of Colobanthus quitensis in the microsporangium with disintegrating tapetum (ta) and differentiated endotecium (en). Ultrastructure of a microspore wall: sexine (se), nexine (ne) and intine (arrow). Distinct apertures (ap) are visible in the sporoderm. $18000 \mathrm{x}$.

Fig. 6. Membrane-like layer (tapetal membrane) with attached orbicules (arrows) are visible. $18000 \mathrm{x}$.

Fig. 7. Ultrastructure of bicellular pollen grains. Cell wall separating a generative cell and a vegetative cell (arrow) is visible. Dense cytoplasm and a nucleus with a nucleole. $18000 \mathrm{x}$. 
with callose and other polysaccharides does not develop here, contrary to most angiosperms ( $\mathrm{Charzyńska}$ and L ew an d ow s ka, 1990; R odk i ew i c z et al. 1996). The further development of Colobanthus quitensis pollen takes place in a similar way to other species with trinucleate pollen. The generative cell remains firmly attached to the cell wall and, in this position, divides mitotically producing two sperm cells.

This is different in the microspores of many described angiosperms with binucleate pollen ( $\mathrm{M}$ a s c a re nh a s, 1989; R o d ki ew i c z et al., 1996). In these species, soon after mitosis, sometimes after an hour for example, the generative cell breaks off the sporoderm and becomes completely immersed in the cytoplasm of the vegetative cell. There it often changes its shape from lenticular to fusiform and pointed at the ends. This shape can be changed and is maintained by cytoskeleton microtubules running parallel to its long axis. In its further development, in pollen or pollen-tube, the generative cell undergoes one more mitosis giving rise to two sperm cells. The elongated shape and transfer of sperm cells and vegetative nucleus, that is the male germ unit, in the pollen-tube of flowering plants is of cytoskeletal origin (Va n Lammeren et al. 1985; 1989; B ed $\mathrm{n}$ a r a , 2003). When two sperm cells are produced after the second mitosis, apart from the common wall or at least plasmatic membranes inherited from the generative cell, they are related by a group of phragmoplast microtubules and, additionally, cortical microtubules which were polymerised earlier and do not disappear despite the beginning of the next mitosis.

The male germ unit of Antarctic pearlwort was observed in a transmission electron microscope. Unfortunately, we failed to photograph the only object. Nevertheless, the morphologic variation of sperm cells, with features as in Plumbago zeylanica (R u s s e 1, 1984) or Brassica (Dumas et al. 1985; Charzyńska et al. 1989), were clearly visible. One sperm cell of Antarctic pearlwort contained mainly plastids, and in the cytoplasm of the other cell, its elongated protrusion stuck in the vegetative nucleus, particularly mitochondria could be observed ( $\mathrm{G}$ i e ł w a n o w s k a, 2005).

Some of the mature trinucleate pollen of Antarctic pearlwort spills out of the anther onto the surface of the feathery stigma and germinates there. The pollen which remains in the microsporangium germinates inside the anther, as is the case in other cleistogamic flowers (Giełwanowska et al. 2006).

\section{CONCLUSIONS}

1. Cleistogamy in Colobanthus quitensis was induced by low temperatures, high air humidity and strong winds.

2. A small number of microspores differentiated in the Colobanthus quitensis microsporangium is typical of cleistogamic species.
3. Mature pollen of Colobanthus quitensis contained a bicellular or tricellular male gametophyte.

4. Some of the mature pollen of Antarctic pearlwort spills out of the anther onto the surface of the feathery stigma and germinates there, but some germinates inside the anther, as is the case in other cleistogamic flowers.

\section{REFERENCES}

Alberdi M., Bravo L.A., Gutiérrez A., Gidekel M., Corcuera L. J., 2002. Ecophysiology of Antarctic vascular plants. Physiol. Plant. 115: $479-486$.

Bednara J., 2003. Rola szkieletu cytoplazmatycznego w rozmnażaniu roślin. / Role of cytoskeleton in plants reproduction. Kosmos, 52(4): 469-479.

Brown R. N. R., 1912. The problems of Antarctic plant life. Rep. Scient. Results Scott natn. antarct. Exped. 3: 1-20.

Charzyńska M., Murigia M., Milanesi C., Cresti M. 1989. Origin of sperm cell association in the "male germ unit" of Brassica pollen. Protoplasma, 149: 1-4.

Charzyńska M., Lewandowska E., 1990. Generative cell division and sperm cell association in the pollen grain of Sambucus nigra. Ann. Bot. 65: 685-689.

Convey P., 1996. Reproduction of Antarctic flowering plants. Antarctic Sci., 8: 127 - 134.

Dumas C., Knox R. B., Gaude T., 1985. The spatial association of the sperm cells and vegetative nucleus in the pollen grain of Brassica. Protoplasma, 124: 168-174.

Edwards J. A., 1974. Studies in Colobanthus quitensis (Kunt) Bartl. and Deschampsia antarctica Desv: VI. Reproductive performance on Singy Island. Br. Antarct. Surv. Bull., 39: 67-86.

Giełwanowska I., Bochenek A., Loro P., 2005. Biology of generative reproduction of Deschampsia antarctica: 181-195, L. Frey (Ed.), W. Szafer Institute of Botany, Polish Academy of Sciences, Kraków.

Giełwanowska I., 2005. Specyfika rozwoju antarktycznych roślin naczyniowych Colobanthus quitensis (Kurth) Bartl. i Deschampsia antarctica Desv. / Specific developmental characters of Antarctic vascular plants Colobanthus quitensis (Kurth) Bartl. i Deschampsia antarctica Desv.: 21-65, Wydawnictwa UWM, Olsztyn.

Giełwanowska I., Szczuka E., Bochenek A., 2006. Zapylenie u antarktycznej rośliny naczyniowej Colobanthus quitensis (Kurth) Bartl. / Pollination in the Antarctic flowering plant Colobanthus quitensis (Kunth) Bartl., Acta Agrobot. 59(1): 123-131.

Greene D. M. i Holtom A., 1971. Studies in Colobanthus quitensis (Kunth) Bartl. and Deschampsia antarctica Desv., III. Distribution, habitats and performance in the Antarctic botanical zone. British Antarctic Survey Bulletin, 26: 1-29.

Heslop-Harrison J., Heslop-Harrison J.S., HeslopHarris on Y., 1986. The comportment of the vegetative cell in the pollen and pollen tubes of Helleborus foetidus L. Ann. Bot. 58: 1-12. 
Holdgate M. W., 1964. Terrestial ecology in the maritime Antarctic. W: Carrick R., Holdgate M.W. and Prevost J., (Ed), Biologie antarctiqe: 181-194. Hermann, Paris.

Holtom A., Green S. W., 1967. The growth and reproduction of Antarctic flowering plants. In: Smith J.E. organizer. A discussion on the terrestrial Antarctic ecosystem. Phil. Trans. R. Soc., Ser. B, 252, 777: 323-370.

Mascarenhas J. P., 1989. The male gametophyte of flovering plants. The Plant Cell, 1: 657-664.

McQuade H. A., Young-Rottler A. M., 1984. Observations on promeiocytes of wheat. Am. J. Bot. 71: 228-238.

Pacini E., Franchi G. G., Bellani L. M. 1985. Pollen grain development in the olive (Olea europaea L.): ultrastructure and anomalies, In: Sexual reproduction in seed plants, ferns and mosses. Eds. M.T.M. Willemse, J.L. van Went., pp. 25-27, Pudoc, Wageningen.

Pearse A. G. E., 1962. Histochemistry. Curchil B.T.D.: 444446, London.

Reynolds E. S., 1963. The use of lead citrate of high $\mathrm{pH}$ as an electron - opaque stain in electron microscopy. J. Cell Biol. 17: 208-212.

Rodkiewicz B., Śnieżko R., Fyk B., Niewęgłowska B., Tchórzewska D., 1996. Embriologia Angiospermae Rozwojowa i Eksperymentalna. / Develpmental and Experimental Embryology of Angiospermae: 34-163, Wyd. UMCS, Lublin.

Russell S. D., 1984. Ultrastructure of the sperm of Plumbago zeylanica. II. Quantitative cytology and three-dimensional organization. Planta, 162: 385-391.

Van Lammeren A. A. M., Keijzer C. J., Willemse M. T. M., Kieft H., 1985. Structure and function of the microtubular cytoskeleton during pollen development in Gasteria verrucosa (Mil.) M. Duval., Planta, 165: 1-11.
Van Lammeren A. A. M., Bednara J., Willemse M. T. M., 1989. Organization of the actin cytoskeleton during pollen development in Gasteria verrucosa (Mill.) H. Duval visualized with rhodamine-phalloidin. Planta, 178: 531-539.

\section{Rozwój pyłku u antarktycznej rośliny naczyniowej Colobanthus quitensis (Kurth) Bartl.}

\section{Streszczenie}

Colobanthus quitensis, jedyna dwuliścienna roślina kwiatowa rosnąca $\mathrm{w}$ ekstremalnie niesprzyjających warunkach antarktycznej strefy geobotanicznej, wykształca zróżnicowane, obupłciowe kwiaty; chasmogamiczne i kleistogamiczne. Kleistogamia jest tu indukowana niską temperaturą, dużą wilgotnością powietrza i silnym wiatrem. W mikrosporangiach Colobanthus quitensis różnicowała się mała liczba mikrospor, co jest cechą typową dla gatunków z kleistogamią. Mikrosporocyty tworzyły bardzo grube kalozowe ściany specjalne. Nie było jednak kalozy w ścianie oddzielającej komórkę generatywną od wegetatywnej. W rozwoju pyłku Colobanthus quitensis zaobserwowano męską jednostkę rozrodczą ze zróżnicowanymi komórkami plemnikowymi. Mniejsza komórka zawierała przede wszystkim mitochondria, a większa głównie plastydy. Dojrzały pyłek wysypywał się z mikrosporangium lub kiełkował na miejscu. Obserwowano trójkomórkowe ziarna pyłku z łagiewkami wewnątrz otwartych pylników. 